\title{
Production Function and Efficiency of Indonesian Fisheries Agroindustry (A study in East Kalimantan Province)
}

\author{
Tri Gunarti Ningrum ${ }^{1} \quad$ Dwijono Hadi Darwanto $^{2} \quad$ Slamet Hartono $^{2} \quad$ Jangkung Handoyo Mulyo $^{2}$ \\ 1. Students in the Doctoral Program,Department of Social Economics of Agriculture, Faculty of \\ Agriculture, Gadjahmada University \\ 2.Department of Social Economics of Agriculture, Faculty of Agriculture, Gadjahmada University
}

\begin{abstract}
Agroindustry development is an effort to improve the quality of human resources in utilizing natural resources optimally. This study aims to determine the production efficiency and competitiveness of fisheries agro-industries in East Kalimantan Province. The analysis model used is the stochastic frontier production function to determine technical, allocative and economic efficiency. This research was conducted in East Kalimantan Province, by taking locations in 5 districts and cities. The types of fisheries agroindustry that are sampled are Amplang agroindustry and salted fish.The results showed that the amplang agro-industry business technically, allocation and economy had an average value that was higher than the salted fish agro-industry. Amplang agro-industry still has a chance to improve technical efficiency by increasing productivity through better management. The average annual output of agang industry is $2010 \mathrm{~kg}$, while the average value of inputs for fish is $714.4 \mathrm{~kg}$, eggs $183.1 \mathrm{~kg}$, flour $1,319.9$ $\mathrm{kg}$, and working time is $247.5 \mathrm{HOK}$. The salted fish industry produces an output of $5,456.7 \mathrm{~kg}$ with an average fish input of $9,716.1 \mathrm{~kg}, 2,110.1 \mathrm{~kg}$ of salt and $829.4 \mathrm{HOK}$ working time.
\end{abstract}

Keywords: agro-industry, fisheries, production function, efficiency, Indonesia

DOI: $10.7176 / \mathrm{JESD} / 10-24-09$

Publication date: December $31^{\text {st }} 2019$

\section{Introduction}

Agroindustry has great potential to grow and has important socio-economic impacts, especially for increasing community income and economic growth. About 14 percent of the total workforce in developed countries actively participates in agro-industry processing both directly and indirectly (Dhiman and Rani, 2011). In the framework of fisheries development, agroindustry is the main driver of the development of the fisheries sector, especially in the future the position of fisheries is a mainstay sector in national development so that the role of agroindustry will be even greater. In an effort to make it happen, the fisheries sector must be supported through the development of resilient, advanced, and efficient and effective agro-industry so that it can become a leading sector in national development.

The development of agroindustry in Indonesia is a necessity in the context of an industrial society based on agriculture in the broad sense and in particular fisheries. This is because the majority of rural people depend their lives on the agriculture/fisheries sector, there is an imbalance between cities and villages so that urbanization is quite high and income levels are low, unemployment is high, foreign exchange is small and food security is weak so that agroindustries are needed to support development in rural.

East Kalimantan is one of the main gateways in the eastern part of Indonesia. The area, also known as a timber warehouse and mining products, has hundreds of rivers spread in almost all districts/cities and is the main means of transportation besides land transportation, with the longest river being the Mahakam River. East Kalimantan has abundant natural resources and has a large potential to be appointed as a commodity of high economic value. Data on East Kalimantan fisheries production can be seen in table 1.

Tabel 1. East Kalimantan Fisheries Production in 2010 - 2015

\begin{tabular}{cccc}
\hline Tahun & Marine Fisheries & Land Fisheries & Total \\
\hline 2010 & $111.702,9$ & $196.918,6$ & $308.621,5$ \\
2011 & $103.406,4$ & $275.423,9$ & $378.830,3$ \\
2012 & $105.392,3$ & $333.351,9$ & $438.744,2$ \\
2013 & $94.679,0$ & $324.781,6$ & $419.460,6$ \\
2014 & $96.850,5$ & $333.692,5$ & $430.543,0$ \\
2015 & $104.622,3$ & $135.337,2$ & $239.959,5$ \\
\hline
\end{tabular}

Source: Ministry of Maritime Affairs and Fisheries, East Kalimantan, 2016

Fisheries agro-industry has a very large role in Indonesia's agricultural development, especially in the context of transforming the economic structure. Indonesia has promoted the development of agro-industry by encouraging and providing ease of investment in the agro-industry sector. The role of agro-industry in changing the commodity characteristics of fisheries is to create new products that are more acceptable to consumers, improve product quality 
and increase product durability. The strategy for developing agro-industries that can be pursued must be adapted to the characteristics and problems of the relevant agro-industry (Soejono, 2008).

At present, the fisheries agroindustry in East Kalimantan has grown rapidly where there are more types or diversifications of food with sea-based raw materials. The potential for raw materials for fisheries agro-industries is very abundant, superior products that have the potential to be developed include envelopes, salted fish, smoked fish, shrimp paste, fish meatballs, empek-empek, nuggets, shellfish chips, and candied seaweed.

The approach of agroindustry through the development of small-scale fisheries-based industries in East Kalimantan is faced with endless structures, starting from the main problems of small-scale business, low business group activities, production business activities are still scattered and the level of knowledge of human resources is still low, quality of production still low which in turn results in low acquisition prices and limited business capital.

The problem of productivity of agroindustry enterprises is closely related to the issue of efficiency of input use, the allocation of use of inputs is still not optimal. One indicator of efficiency is if or a certain amount of output can be produced using a number of combinations of fewer inputs and with a combination of certain inputs can minimize production costs without reducing the output produced. With minimum production costs, more competitive output prices will be obtained (Kurniawan et al., 2008). Efficiency causes a decrease in production costs which will ultimately increase competitiveness. This is very influential on the development of fisheries agroindustry investments in East Kalimantan.

The implications of development not only can increase family income but are expected to be able to grow the fisheries agroindustry and produce products according to regional characteristics so that they can have stronger roots in the economy in the coastal areas of East Kalimantan. With the existence of agroindustry, fishery products can be processed into processed products that can increase added value. Because of that, agroindustry is needed so that the income and welfare of the community can be improved, besides that agroindustry opens up employment opportunities for the local community and creates a multiplier effect.

\section{Literature review}

According to Soekartawi (2000), agroindustry is an industry that has the main raw material from agricultural products where the activity utilizes agricultural products as raw material, designs and provides equipment and services for these activities. Explicitly the notion of agroindustry was first revealed by Austin (1981), a company that processes vegetable and animal ingredients. The process used includes conversion and preservation through physical or chemical treatment, storage, packaging and distribution. This agroindustrial product can be an end product that is ready for consumption or use by humans or as a product of other industrial raw materials.

Fisheries agroindustry can be interpreted as an integrated unit starting from the provision of raw materials, processing, to marketing. The purpose is to provide added value to fishery products, secure production because of the perishable nature of products, diversification of fishery products, ensure continuity of fish availability throughout the year, and increasing the marketing range of fish at a dynamic level of demand.

Management of agroindustry can be said to be unique, because the raw materials derived from agriculture have three characteristics, namely seasonality, perishability, and variability (Austin, 1981). Three other characteristics that need attention are: first, because the component of raw material costs is generally the largest component in agro-industry, the process of bringing in raw materials greatly determines the operation of agroindustrial companies. Uncertainty in agricultural production can cause instability in raw material prices, thereby complicating funding and managing working capital. Second, because many agro-industry products are needs that must be met or are important commodities for the economy of a country, the government's attention and involvement in agro-industry activities are too high. Third, because an agroindustrial product may be produced by several countries, local agro-industries are linked to the international market as an alternative market for raw materials, competitive imports, and export opportunities. High commodity price fluctuations in the international market increase financial uncertainty on the input and output side.

Agroindustry processing of fishery products is part of agroindustry that processes raw materials sourced from aquatic animals. Processing in question includes processing in the form of transformation and preservation through physical or chemical changes, storage, packing and distribution. Processing can be in the form of simple processing such as cleaning, grading, packing or can also be more sophisticated processing, such as milling, powdering, extraction and distillation (extraction), frying (roasting), spinning, canning, and other manufacturing processes.

Fisheries agroindustry research can be seen in Soejono's (2008) study, which examined the pattern of marine fisheries-based agroindustry development in Puger District, Jember Regency, this study aims to determine the level of efficiency of the use of production costs and net income obtained by entrepreneurs The ratio, calculation of shrimp paste agroindustry cost efficiency shows that the $\mathrm{R} / \mathrm{C}$ ratio obtained is 1.82 or greater than 1 . That is, if the manager adds a fee of $\mathrm{Rp} 1$, in the production process, it will get a profit of $\mathrm{Rp} 1.82$ with a rate profit of 0.82 while for 1.23 fish crackers, pindang fish 1.31, and fish meal products $\mathrm{R} / \mathrm{C}$ ratio 1.17.

Similar research on the efficiency of fishery agroindustry using the Cobb-Douglas function model can be seen in the research of Setiawati (2006), about the analysis of the influence of production factors on the fish fuming 
industry in the city of Semarang.

Fourteen of the 20 elements of productivity management were significantly correlated with performance indicators with three elements (participation in organic cocoa production, farmer schools, and pricing). This is in line with the agro-industry research conducted by Seranevijaikitkhan, et.al. (2008) about increasing production efficiency which is a case study on ground coffee agroindustry, from the results of the study, found that the comparison between labour increase in sorting operations (alternative 1) and using automatic sorting machines (alternative 2) based on the payback period indicate that investment in sorting machines to replace workers is better, especially when demand increases. It only takes a few years to pay for the machine and save more money than the first alternative. The use of sorting machines also has a number of other advantages. This can clear the bottleneck in the sorting operation and completely eliminate the amount of work waiting, thus making the waiting time in this operation zero. An important benefit is that sorting machines can carry out sorting operations to get rid of physical contamination (eg, rock, soil, wood chips, glass, etc.) and produce higher quality coffee beans if using human workers, which results in more product quality well.

\section{Methodology}

\subsection{Sample}

Amplang Agroindustry and Salted Fish are agro-industries analyzed in this study, which is based on the type of agro-industry that is relied upon by the Provincial Government of East Kalimantan and the highest number of agro-industry entrepreneurs. Furthermore, the sample of agro-industry entrepreneurs in this study was determined based on a purposive sampling method in which samples were deliberately taken based on predetermined criteria.. The number of respondents was determined as many as 30 people from each type of agroindustry considering the characteristics of homogeneous samples and in accordance with the minimum requirements of parametric statistics (Singarimbun and Efendi, 1989).

\subsection{Data analysis method}

\subsubsection{Technical Efficiency Analysis and Inefficiency}

The general formulation for measuring technical efficiency achieved by the first observation at t-time according to Coelli (1996) is:

$$
\begin{aligned}
& T E_{i}=\frac{Y_{i}}{Y_{i}^{*}}=\frac{E\left(Y \mid U_{i}, X_{i}\right)}{E\left(Y^{*} \mid U_{i}=0, X_{i}\right)}=E\left[\exp \left(-U_{i}\right) \mid \varepsilon_{i}\right] \\
& T E=E\left[\exp \left(-U_{i} \mid \varepsilon\right] i=1,2,3, \ldots n\right. \\
& \text { Information: }
\end{aligned}
$$

\section{TEi $=$ Technical efficiency of the 1st entrepreneur}

$\mathrm{Yi}=$ Deterministic output function (without error term)

$\mathrm{Ui} \quad=$ a random variable that describes the technical inefficiencies of the $\mathrm{i}$ th business which is assumed to be free and the distribution is cut off normally by $\mathrm{N}(\mu \mathrm{i}, \sigma 2)$

The measure of technical efficiency of each individual agroindustry entrepreneur can be calculated based on the expected value of the $\mathrm{u}_{\mathrm{it}}$ with the terms $\varepsilon_{\mathrm{it}}$.

$\boldsymbol{E}_{(\boldsymbol{u} / \boldsymbol{v})}=\frac{\boldsymbol{\sigma}_{\boldsymbol{u}} \sigma_{v}}{\sigma}\left|\frac{\boldsymbol{f}\left(\boldsymbol{\epsilon} \frac{\lambda}{\sigma}\right)}{\mathbf{1}-\boldsymbol{F}\left(\frac{\boldsymbol{\lambda}}{\boldsymbol{\sigma}}\right)}-\frac{\epsilon \lambda}{\sigma}\right| \quad \mathrm{i}=1,2,3, \ldots \mathrm{n}$

Information :

$\mathrm{f}^{*}$ and $\mathrm{F}^{*}$ are normal standard density functions and normal standard distribution functions. Because $\mathrm{N}(\mu \mathrm{i}, \sigma 2)$ is not negative, the amount of TE is at interval $0-1$ or $0 \leq \mathrm{TEi} \leq 1$.

To analyze the effect of the use of production factors on the production of fisheries agroindustry using the CobbDouglas formula with estimation equations:

1. Amplang agroindustry

$$
\begin{gathered}
\ln Y_{P}=\ln \propto+\propto_{1} \ln X_{i k}+\propto_{2} \ln X_{T l}+\propto_{3} \ln X_{T p}+\propto_{4} \ln X_{H o k}+\delta_{0}+\delta_{1} \ln U M+\delta_{2} \ln P D+ \\
\delta_{3} \ln \mathrm{ART}+\delta_{4} \ln P G L+\left(v_{i}-u_{i}\right)
\end{gathered}
$$

Information :

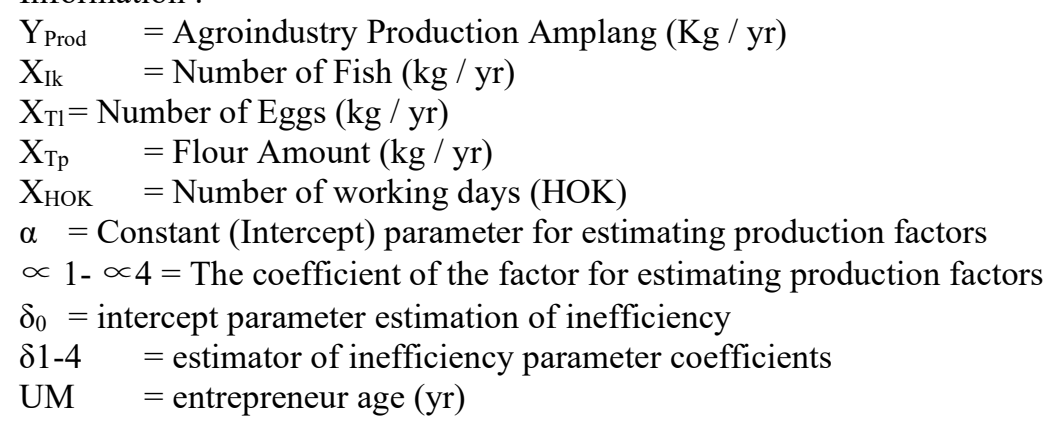


$\mathrm{PD}=$ education $(\mathrm{yr})$

JAK = number of family members (people)

PGL = experience of being an entrepreneur $(\mathrm{yr})$

$\left(\mathrm{v}_{\mathrm{i}}-\mathrm{u}_{\mathrm{i}}\right)=$ Error term

2. Salted fish agroindustry

$\ln Y_{P}=\ln \propto+\propto_{1} \ln X_{i k}+\propto_{2} \ln X_{g r}+\propto_{3} \ln X_{H O K}+\delta_{0}+\delta_{1} \ln U M+\delta_{2} \ln P D+$

$$
\delta_{3} \ln \mathrm{ART}+\delta_{4} \ln P G L+\left(v_{i}-u_{i}\right)
$$

Information:

$\mathrm{Y}_{\text {Prod }} \quad=$ Production of salted fish agroindustry $(\mathrm{Kg} / \mathrm{yr})$

$\mathrm{X}_{\mathrm{Ik}}=$ Number of Fish $(\mathrm{kg} /$ year)

$\mathrm{X}_{\mathrm{Gr}} \quad=$ Amount of Salt $(\mathrm{kg} /$ year $)$

$\mathrm{X}_{\mathrm{Tk}} \quad=$ Number of working days (HOK)

$\alpha=$ Constant (Intercept) parameter to estimate the factors of production

$\propto_{1}-\propto_{4}=$ Factor coefficient to estimate production factors

$\delta_{0}=$ intercept parameter estimation of inefficiency

$\delta_{1-4}=$ coefficient parameter inefficiency estimator

$\mathrm{UM}=$ entrepreneur age $(\mathrm{yr})$

$\mathrm{PD}=$ education $(\mathrm{yr})$

JAK = number of family members (people)

PGL = experience of being an entrepreneur $(\mathrm{yr})$

$\left(\mathrm{v}_{\mathrm{i}}-\mathrm{u}_{\mathrm{i}}\right)=$ Error term

Testing the stochastic frontier parameters and the effects of technical inefficiency are carried out in two stages. The first stage is estimating $\beta_{1}$ parameters using Ordinary Least Squares (OLS). The second stage is the estimation of all parameters $\beta_{0}, \beta_{1}$, variations of $u_{i}$ and $v_{i}$ using the Maximum Likelihood (MLE) method using the Frontier computing program version 4.1 developed by Coelli (1996).

The results of processing the Frontier 4.1 program according to Aigner, et al. (1977) and Greene (1993) in Coelli, et al (1996) will provide the estimated variance parameters in the following form:

$$
\sigma^{2} \equiv \sigma_{u}^{2}+\sigma_{v}^{2} \text { and } \gamma \equiv \frac{\sigma_{u}}{\delta_{v}}
$$

Informations :

$\sigma^{2}=$ normal distribution variance

$\sigma_{u}^{2}=$ variance $\mathrm{u}_{\mathrm{i}}$

$\sigma_{v}^{2}=$ variance $\mathrm{v}_{\mathrm{i}}$

The parameter value $\gamma$ is a contribution of technical efficiency in the residual error $(\varepsilon)$ whose value ranges between zero and one. The parameter value $\gamma$ which is close to zero indicates that the deviation from the frontier leads to a residual (error) effect, while the value close to one indicates that the deviation is increasingly leading to the effect of technical inefficiency.

\subsubsection{Economic and Allocative Efficiency Analysis}

The measurement of economic and allocative efficiency is done by reducing the dual cost function of the frontier stochastic production function by minimizing the input cost function with the constraints of the production function as follows:

1. Amplang Agroindustry

$$
\ln Y_{\text {BProd }}=\beta_{0}+\beta_{1} \ln X_{J p r o d}+\beta_{2} \ln X_{h i k}+\beta_{3} \ln X_{h t l}+\beta_{4} \ln X_{h t p}+\quad \beta_{5} \ln X_{H O K}+\left(v_{i}-u_{i}\right)
$$

Information :

$\mathrm{Y}_{\text {Bprod }}=$ production cost $(\mathrm{Rp})$

$\mathrm{X}_{\mathrm{Jprod}}=$ total production $(\mathrm{kg})$

$\mathrm{X}_{\text {Hik }} \quad=$ Fish price $(\mathrm{Rp})$

$\mathrm{X}_{\mathrm{htl}} \quad=$ Price of eggs $(\mathrm{Rp})$

$\mathrm{X}_{\mathrm{Htp}} \quad=$ Price of flour $(\mathrm{Rp})$

$\mathrm{X}_{\mathrm{hok}} \quad=$ Labour salary $(\mathrm{Rp})$

$\beta_{0} \quad=$ Constants (Intercept)

$\beta_{1-} \beta_{5}=$ Coefficient of estimator parameters

$\left(\mathrm{v}_{\mathrm{i}}-\mathrm{u}_{\mathrm{i}}\right) \quad=$ Error term

2. Salted fish agroindustry

$\ln Y_{\text {BProd }}=\beta_{0}+\beta_{1} \ln X_{J p r o d}+\beta_{2} \ln X_{h i k}+\beta_{3} \ln X_{g r}+\beta_{4} \ln X_{h o k}+\left(v_{i}-u_{i}\right)$ Information:

$\mathrm{Y}_{\mathrm{BProd}}=$ production cost $(\mathrm{Rp})$

$\mathrm{X}_{\mathrm{JProd}}=$ total production( $\mathrm{kg}$ ) 
$\mathrm{X}_{\text {Hik }} \quad=$ Fish price $(\mathrm{Rp})$

$\mathrm{X}_{\mathrm{htl}} \quad=$ Price of eggs (Rp)

$\mathrm{X}_{\mathrm{Htp}} \quad=$ Price of flour (Rp)

$\mathrm{X}_{\text {hok }} \quad=$ Labour salary $(\mathrm{Rp})$

$\beta_{0} \quad=$ Constants (Intercept)

$\beta_{1}-\beta_{4}=$ Coefficient of estimator parameters

$\left(\mathrm{v}_{\mathrm{i}}-\mathrm{u}_{\mathrm{i}}\right) \quad=$ Error term

Economic efficiency according to Jondrow (1982) is the ratio between the total actual production costs (C) with the minimum total production costs observed or supposed to $\left(\mathrm{C}^{*}\right)$ formulated as follows:

$E E \frac{c_{i}}{c_{i}^{*}}=\frac{E\left(c_{i} \mid U_{i}=0, Y_{i} P_{i}\right)}{E\left(Y_{i} \mid U_{i}, Y_{i}, P_{i}\right)}=E\left\lfloor\exp \left(-U_{i} \mid \varepsilon\right)\right\rfloor$

Economic efficiency values range between 0 and 1. Based on Ogundari and Ojo (2006) using the Frontier 4.1 program application, the value of Cost Efficiency (CE) will be obtained, which was initially calculated as the inverse of equation (10), thus economic efficiency (EE) fisheries agroindustry obtained from inverse Cost Efficiency (CE) using the formula:

$E E=\frac{1}{\text { Cost Efficiency }(C C)}$

Economic efficiency will be achieved if technical efficiency or technical efficiency (TE) and allocative efficiency or Allocative Efficiency (AE) have been achieved, so that to find allocative efficiency (AE) can be formulated:

$A E=\frac{\text { Economic Efficiency }(E E)}{\text { Tehnical Efficiency }(T E)}$

In previous studies conducted by Ogundari and Ojo (2006), Nwaru, et.al (2011), Laha and Kuri (2011), divide the level of efficiency based on the following criteria:

i. Very efficient: TE, $\mathrm{EE}$ and $\mathrm{AE} \geq 0.90$

ii. Efficient enough: $0.70 \leq \mathrm{TE}, \mathrm{EE}$ and $\mathrm{AE}<0.90$

iii. Not efficient: TE, $\mathrm{EE}$, and $\mathrm{AE}<0.70$

\section{Result and Discussion}

This study uses the stochastic-frontier model which is the Cobb-Douglas productivity function with the Maximum Likelihood Estimate (MLE) method. The Frontier 4.1 program is used to find the MLE value, the program is divided into two, namely the initial stage using the Ordinary Least Square (OLS) method to estimate the technological parameters and production inputs, and the second stage uses the Maximum Likelihood Estimate method to estimate the overall input intercept and the variance of both the vi and ui error components. There are 2 (two) types of agroindustry used in this study, namely Amplang Agroindustry and Salted Fish. Each type of agroindustry requires input and produces different outputs.

Analysis of the Stochastic Frontier Production Function:

1. Amplang Agroindustry

The production factor used to estimate amplang agroindustry production is fish, eggs, flour, and working days. The estimation results of the stochastic frontier function can be seen in table 2.

Table 2. Results of Estimation of Fisheries Stochastic Frontier Agroindustry Production Function using OLS and MLE method at Amplang Agroindustry

\begin{tabular}{lccccc}
\hline \multirow{2}{*}{ Variable } & \multirow{2}{*}{ Parameter } & \multicolumn{3}{c}{ OLS } & \multicolumn{2}{c}{ MLE } \\
\cline { 2 - 6 } & & C & t-ratio & C & t-ratio \\
\hline Intercept & $\alpha$ & $1,096^{*}$ & 1,867 & $0,328^{\text {ns }}$ & 1,159 \\
Fish & $\alpha_{1}$ & $0,319^{\text {ns }}$ & 1,153 & $0,799^{* * *}$ & 7,168 \\
Egg & $\alpha_{2}$ & $0,263^{\text {ns }}$ & 1,103 & $-0,192^{*}$ & $-1,775$ \\
Flour & $\alpha_{3}$ & $0,353^{\text {ns }}$ & 1,154 & $0,323^{* * *}$ & 2,613 \\
HOK & $\alpha_{4}$ & $0,104^{*}$ & 1,700 & $0,169^{* * *}$ & 9,920 \\
\hline Sigma Squared & & 0.027 & & $0,116^{\text {ns }}$ & 0,761 \\
Gamma & & & $0,993^{* * *}$ & 91,753 \\
Log Likehood Function & & 14,339 & & 22,214 & 15,749 \\
LR Test & & & & \\
\hline
\end{tabular}

Source: Primary data analysis, 2017

Information :

$\begin{array}{lll}* * * \quad: \text { Significant at the level of } \alpha=0,01 ; t_{\text {table }} & =2,77 \\ * * \quad: \text { Significant at the level of } \alpha=0,05 ; t_{\text {table }} & =2,05 \\ * & \text { : Significant at the level of } \alpha=0,10 ; t_{\text {table }} & =1,70\end{array}$

Based on Table 2, it can be explained partially, one of the four estimating variables of the amplang production 
function has a significant and significant effect with the OLS method, namely labor (at the level of $\alpha=0.10$ ). Expectation value for all positive variables means that if the number of raw materials for fish, eggs, flour and labor increases by 1 percent, it will increase the production of envelopes by 0.319 percent; 0.263 percent; 0.353 percent, and 0.104 percent assuming cateris paribus. The value of the three variables of fish, eggs and flour is not significant due to the entrepreneurs sampled producing a fairly high production range of envelopes, where the average businessman in Samarinda uses $50 \mathrm{~kg}$ of fish raw material while in Sangata District some samples produce envelopes by only using $1 \mathrm{~kg}$ of fish, so the use of eggs and flour is also small.

Based on table 2 can be written the envelope agroindustry stochastic frontier production function model with the estimated MLE as follows:

In $Y_{\text {Prod }}=0.328+0,799 \ln I k-0,192 \ln \mathrm{Tl}+0,323 \mathrm{Tp}+0,169 \ln$ Hok $+\left(\mathrm{vi}_{i}-\mathrm{u}_{\mathrm{i}}\right)$

The intercept value of 0.328 at anti $\ln$ becomes 1.388 indicating that if the independent variable (X) of the amplang agroindustry is zero then the business can still produce 1,388 or the value of the average $\mathrm{Y}$ variable is 1.388 if the $\mathrm{X}$ variable (independent) is 0 . Sigma parameter -squared $(\sigma 2)$ is the total variance value of the effects of technical inefficiencies (ui) and noise (vi). The calculation results obtained by the sigma squared value of 0.116 , this shows that 88.4 percent of the models used are correct. The sigma squared value is not significant because the input and output in the amplang agroindustry can be controlled so that nothing is damaged.

Based on the estimation results of the stochastic frontier production function, this model has a gamma parameter value $(\gamma)$ of 0.993 . The gamma parameter $(\gamma)$ shows the difference between actual production and frontier production caused by inefficiency factors. If the gamma value approaches 1 then the error term only comes from the effect of inefficiency and if the value is close to zero, all error terms contained in the production function model come from noise (season, weather, and modeling errors). The gamma value of 0.993 means that 99.3 percent of the errors originated from the effect of inefficiency and only 0.7 percent came from the effects of noise such as the effect of weather, seasons and modeling errors.

The value of the log like a function with the MLE method is 22,214, this value is greater than the value of the $\log$ like a function with the OLS method $(14,339)$. This shows that the production function with the MLE method is good and in accordance with conditions in the field.

The LR test value is 15,749 from the production function of the stochastic frontier and is greater than the table value $(11,34)$ obtained from the mixed X2 (chi-squared) distribution table in the Kodde and Palm table, with a statistically significant ratio of $\alpha=1$ percent. This means that the frontier's production function can explain the existence of efficiency and technical inefficiency of the envelope entrepreneurs in the production process.

Estimated parameter values in the amplang agroindustry production function for fish, flour, and labor have positive signs, this is as expected, while for eggs marked negative and this is not as expected. Variables of fish, eggs, flour, and labor have a significant effect on amplang production.

Fish, flour and labor raw material variables have a positive effect with a coefficient of $0.799 ; 0.323$ and 0.169 which have a significant or significant effect on the confidence level of 90 percent and 99 percent of the amplang agroindustry production. This value shows that the level of production is directly proportional to the variables of fish, flour, and labor. An increase in the amount of fish, flour and labor by 10 percent will result in an increase in envelope production of 7.99 percent; 3.23 percent, and 1.69 percent assuming other inputs remain (cateris paribus).

Positive relationships and the influence of fish raw material variables on increased amplang production can explain that an increase in fish production is one way to increase amplang production. The effect is significantly caused by fish as the main ingredient in making envelopes, the more raw materials used, the greater the production rate. According to the quality standards of fish crackers issued by SNI (1999) the quality of the envelope is determined by the content of fish in the envelope, the greater the number of fish, the higher the quality of the envelope, and the quality of the fish, the quality of flour and the salinity of the water. The Fisheries Quality Control and Testing Center (2001) states that to get good envelope quality, you should use fish that have just died because the best elasticity of fish meat is only obtained from fresh fish. In general, agroindustry entrepreneurs produce envelopes with a constant amount of production. Production increases generally only occur on major religious holidays, long holidays and if there are regional activities (Erau). The increase in production at that time was very high due to the demand for envelopes to be used as souvenirs and offerings to guests so that Amplang entrepreneurs would take advantage of the opportunity by increasing the amount of production.

Flour has a coefficient value of 0.323 and has a significant effect on the confidence level of 99 percent. The flour used for making envelopes is tapioca flour but there are also respondents who use sago flour. Both have almost the same properties so that their use can be exchanged. Tapioca flour has high carbohydrates because it comes from extracting cassava tubers and influences the crispness of the envelope.

Labor has a positive effect on the technical efficiency of envelope agroindustry by 0.169 , this shows that the addition of a workforce of 10 percent will increase the production of envelopes by 1.69 percent. The value of positive and significant labor elasticity towards amplang production shows that labor is one of the keys to increasing amplang production. An adequate source of labor and having good managerial skills and abilities greatly determines various decisions in production activities so that production becomes better. Some samples only use 
labor in the family, while for amplang businesses that produce in large quantities use outside labor which is paid in bulk. The direction of labor relations and positive production means that labor is an important factor in production, this is in accordance with the theory that labor is a population in working age (aged 15-64 years) who can produce goods and services, if there is a demand for labor them and if they want to participate in these activities (Mulyadi, 2002).

2. Salted Fish Agroindustry

The production factor used to estimate salted fish agroindustry production is fish, salt and labour. Table 3 shows the results of estimation of the production function of the stochastic frontier using the OLS and MLE methods for salted fish agroindustry.

Table 3. Estimation of Production Function of Fisheries Stochastic Frontier Agroindustry using OLS and MLE method in Salted Fish Agroindustry

\begin{tabular}{lccccc}
\hline \multirow{2}{*}{ Variable } & \multirow{2}{*}{ Parameter } & \multicolumn{2}{c}{ OLS } & \multicolumn{2}{c}{ MLE } \\
\cline { 3 - 6 } & $\alpha$ & $0,348^{\text {ns }}$ & 0,660 & $0,687^{\text {ns }}$ & 0,923 \\
Intercept & $\alpha$ & $0,789^{* * *}$ & 3,013 & $0,782^{* * *}$ & 4,041 \\
Fish & $\alpha_{1}$ & $0,043^{*}$ & 0,170 & $0,081^{\text {ns }}$ & 0,423 \\
Salt & $\alpha_{2}$ & $0,103^{* *}$ & 2,020 & $0,089^{*}$ & 2,042 \\
HOK & $\alpha_{3}$ & 0,021 & & $0,015^{* * *}$ & 3,866 \\
\hline Sigma Squared & & & $0,999^{*}$ & 1,734 \\
Gamma & & 17,303 & & 20,358 & \\
Log Likehood Function & & & & 6,109 & \\
LR Test & & & &
\end{tabular}

Source: Primary Data Analysis, 2017

Information:

$\begin{array}{lll}* * * \quad: \text { Significant at the level of } \alpha=0,01 ; t_{\text {table }} & =2,77 \\ * * & : \text { Significant at the level of } \alpha=0,05 ; t_{\text {table }} & =2,05 \\ * & : \text { Significant at the level of } \alpha=0,10 ; t_{\text {table }} & =1,70\end{array}$

Based on table 3, the estimation equation can be written using the MLE method as follows:

$\ln \mathbf{Y}_{\text {Prod }}=0,687+0,782 \ln \mathrm{Ik}+\mathbf{0 , 0 8 1} \ln \mathrm{Gr}+\mathbf{0 , 0 8 9} \ln \mathrm{HOK}+\left(\mathrm{vi}_{\mathrm{i}}-\mathrm{u}_{\mathrm{i}}\right)$

Based on the estimation of the production function of the stochastic frontier of salted fish agroindustry, this model has a gamma paramer value $(\gamma)$ of 0.999 . The gamma parameter $(\gamma)$ shows the difference between actual production and frontier production caused by inefficiency factors in the model. If the gamma value approaches 1 then the error term only comes from the effect of inefficiency and if the value is close to zero, all error terms contained in the production function model come from noise (season, weather, and modelling errors). The gamma value is 0.999 which means that 99.9 per cent of the errors originated from the effect of inefficiency and only 0.1 per cent came from the effects of noise such as the effect of weather, seasons and modelling errors.

The value of the log like a function with the MLE method is 20,358, this value is greater than the value of log like a function with the OLS method (17,303). This shows that the production function with the MLE method is good and in accordance with conditions in the field.

The LR test value of 6.109 from the stochastic frontier production function is greater than the table value (5.99) obtained from the mixed X2 (chi-squared) distribution table in the Kodde and Palm table with a statistically significant ratio of $\alpha=95$ per cent. This means that the frontier's production function can explain the existence of efficiency and technical inefficiency of salted fish entrepreneurs in the production process.

The regression variable for fish variables in salted fish agroindustry is 0.782 and is significant at the 0.01 confidence level. This value shows that if there is an addition of fish raw materials by 10 percent, then there will be a production increase of 7.82 percent.

Fish raw materials are a major component in salted fish processing business so that if there is no or less supply of fish raw materials it will disrupt the production process. Therefore, the sustainability of salted fish processing business will greatly depend on the condition of the fish stock. This results in when the west wind season or bad weather fishermen cannot go to sea so that small-scale salted fishers do not produce. Likewise, vice versa in the season salted fish processing fish produce more salted fish.

Regression coefficients for salt variables are positive (0.081) and not significant, meaning that the value indicates if there is an addition of a salt of 10 per cent, then there will be a production increase of 0.81 per cent, this small increase is due to consumers preferring dry fish that is not so salty. Consumer preferences for salted fish are different, thus the use of salt inputs in salted fish agroindustry can be adjusted according to consumer tastes (Sutarni, 20013). The process of making salted fish consists of two stages, namely salting and drying, the function of the salt inhibits bactericidal growth while drying aims to reduce the water content of the material, also to stop the growth of microbes and enzymes that cause damage to fish (Djariah, 1995). The concentration and amount of salt used in the production of salted fish will determine the quality of salted fish, if the amount of salt is excessive 
it will result in the appearance of salted fish, the taste and texture of hardened salted fish.

The labour variable is positive (0.089) and according to expectations, meaning that if the workforce increases by 10 per cent, there will be a production increase of 0.89 per cent. Statistically, the variable labour value has a significant effect on salted fish production. The use of large amounts of labour is carried out when cleaning up to drying fish while when reversing fish does not use a lot of labour. In addition, during the fish season, the use of labour is more than when it is not season fish.

\section{Conclusion}

The results of the calculation of fisheries agroindustry for Amplang business, smoked fish and shrimp paste have been quite efficient both technically, allocatively and economically, while salted fish agroindustries are technically not efficient, while allocatively and economically are efficient. The factors of age, education, number of family members and experience did not significantly influence inefficiency.

Positive relationships and the influence of fish raw material variables on increased amplang production can explain that an increase in fish production is one way to increase amplang production. The effect is significantly caused by fish as the main ingredient in making envelopes, the more raw materials used, the greater the production rate.

The value of positive and significant labor elasticity towards amplang production shows that labor is one of the keys to increasing amplang production. An adequate source of labor and having good managerial skills and abilities greatly determines various decisions in production activities so that production becomes better.

Fish raw materials are a major component in salted fish processing business so that if there is no or less supply of fish raw materials it will disrupt the production process. Therefore, the sustainability of salted fish processing business will greatly depend on the condition of the fish stock. The concentration and amount of salt used in the production of salted fish will determine the quality of salted fish, if the amount of salt is excessive it will result in the appearance of salted fish, the taste and texture of hardened salted fish.

The variable labour value has a significant effect on salted fish production. The use of large amounts of labour is carried out when cleaning up to drying fish while when reversing fish does not use a lot of labour. In addition, during the fish season, the use of labour is more than when it is not season fish.

\section{References}

Austin, J.E. 1981. Agroindustrial Project Analysis. The Johns Hopkins University Press. London. 274p.

Coelli, T.J. 1996. A Guide to Frontier Version 4.1 : A Computer Program for Stochastic Frontier Productin and Cost Function Estimation. CEPA Working Paper No 7/96. Departement of Econometrics. University of England. Armidale.

Dhiman, P.K and A. Rani, 2011, Problems And Prospects Of Small Scale Agro Based Industries: An Analysis Of Patiala District. International Journal Of Multidisciplinary Research. 1(4):129-142.

Djariah, U.S. 1995. Ikan Asin. Kanisius Publisher. Yogyakarta. 56 p.

Jondrow, J., C.A.K. Lovell., I.S Materov \& P. Schmidt. 1982. On Estimation of Technical Inefficiency in The Stochastic Frontier Production Function Models. Journal of Econometric. 19:223-238.

Kurniawan, A.Y., S. Hartoyo \& Y. Syaukat. 2008. Analysis of Economic Efficiency and Corn Competitiveness in Dry Land in Tanah Laut District, South Kalimantan. Postgraduate Forum. 31 (2): 93-103.

Mulyadi, S. 2002. Human Resource Economics. Raja Grafindo Persada. Jakarta. 227p.

Nwaru, J.C., U.A. Essien \& R.E. Onuoha. 2011. Determinantsof informal Credit Demand and Supply Among Food Crop Farmers in Akwa Ibom State. Nigeria Journal of Rural and Community Development. 6(1):129139

Ogundari, K. \& S.O. Ojo. 2006. An Examination of Technical, Economic and Allocative Efficiency of Small Farm: The Case Study of Cassava Farmers in Osun State of Nigeria. Journal Central European Agriculture. 7(3):423-432.

Seranevijaikitkhan W, P. Parthanadee \& B. Jirachai. 2008. Production efficiency improvement: case study in roasted and ground coffee industry. As. J. Food Ag-Ind. 1(02):105-115.

Singarimbun. M \& Effendi, S. 1989. Survey Research Methods. Jakarta, LP3ES.

SNI (Indonesian National Standard). 1999. Fish Crackers. SNI 01-2913-1999. National Standardization Agency: Palembang.

Soejono, D. 2008. Patterns of Development of Marine Fisheries-Based Agro-Industry in Puger District, Jember Regency. J-SEP. 2 (1): 30-37p.

Sutarni. 2013. Factors Affecting Preservation of Salted Teri Fish Production in Labuhan Maringgai District, East Lampung Regency. ESAI Scientific Journal. 7 (1): 1-14. 